\title{
Social Embeddedness of Technology: Prospective Research Areas
}

\author{
Maria Dobryakova, Zoya Kotelnikova
}

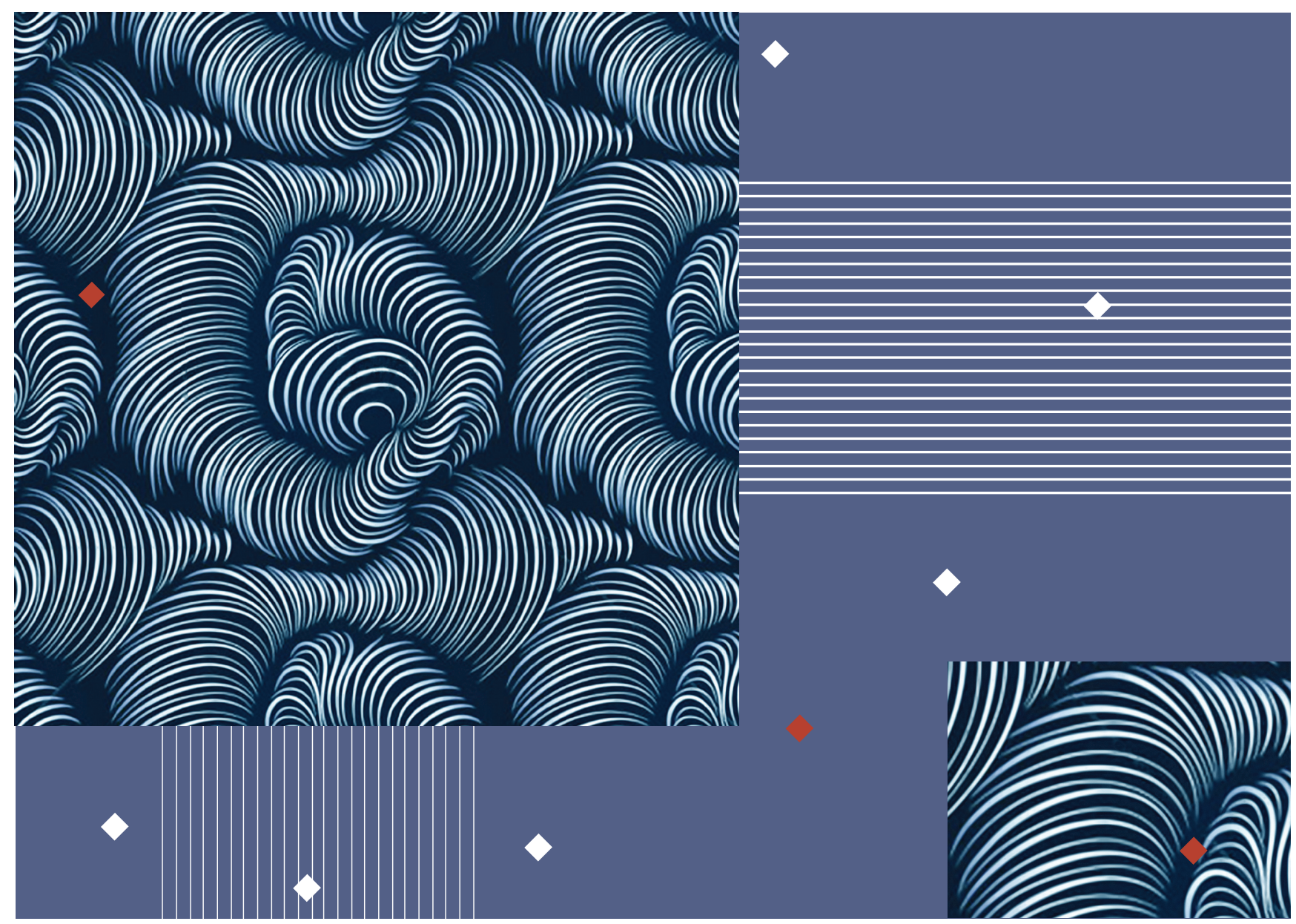

Strategic documents that reflect future S\&T priorities are often formulated without sufficiently taking into account the social context of S\&T developments. Using the concept of the social construction of technology (SCOT), the paper discusses the capabilities of social sciences for a deeper contextual analysis when setting priorities and, consequently, for helping to make the diffusion of advanced technologies more efficient. It proposes prospective areas of sociological research, whose development may help optimize efforts for the diffusion of new technologies.
Maria Dobryakova - Head, Division for Sociological Studies, Institute for Statistical Studies and Economics of Knowledge. E-mail: mdobryakova@hse.ru

Zoya Kotelnikova - Senior Research Fellow, Laboratory for Studies in Economic Sociology. E-mail: kotelnikova@hse.ru

National Research University - Higher School of Economics.

Address: 11, Myasnitskaya str., Moscow 101000, Russian Federation

\section{Keywords}

social construction of technology (SCOT); diffusion of innovation; social embeddedness; social sciences; humanities; prospective research areas

DOI: 10.17323/1995-459X.2015.1.6.19 
$\mathrm{D}$ evelopment in industrial countries is largely based on achievements in science, technology and innovation; indeed, the latter are often considered a key source of economic growth. Ambitious transitional economies strive for this very model. In this respect, planned scientific and technological developments and spontaneous flashes of genius by certain creative groups are thoroughly supported by carefully thought out forecasts and programmes; countries and regions develop these forecasts and programmes taking into account their own interests and circumstances, fixing their developmental priorities and identifying 'critical technologies' and resource opportunities and limitations. In this article, we combine two lines of discussion that are developing in parallel: a social analysis of the relationships between humans and technology on the one hand, and strategic planning, forecasting in prospective technology selection and prospective technology implementation, on the other hand. The aim of this study is to show the opportunities offered by the social sciences and humanities to carry out a more in-depth contextual analysis when formulating country developmental priorities and, ultimately, to raise the effectiveness of policy making in science, technology, and innovation.

\section{Methodological framework: how do innovations take root?}

In programme documents on science and technology priorities, science and society have long been viewed as separate entities: it was believed that society is a 'benign recipient' of scientific achievements [Forsberg et al., 2015, p.22]. However, social distrust of certain scientific developments has caused growing concern: a striking example of this is genetically modified foods [Ibid., p.21]. Society has gradually started to see scientific progress as a key reference point in decision making. The analytical document 'Science, society and the citizen in Europe' produced by the European Commission argues for a rethink about the relationship between science, technology and society [CEC, 2000]. ${ }^{1}$ The concept of 'responsible research and innovation', which proposes taking into account the social and ethical effects of developments, has well and truly taken off [Stahl, 2013; Stahl et al., 2014; Frewer et al., 2014; Bremer et al., 2015; Forsberg et al., 2015].

Technology has traditionally been assigned the role of a key driving force, influencing change in social and economic conditions in a certain way. In fact, the latter are rather seen as a resource factor, and the relationship between humans and technology is not broached at all. Recent literature on assessing obstacles to the spread of advanced technology in achieving social and economic goals raises questions about improving scenarios, road maps, methods to identify weak signals and best practices [Mahroum, 2012; Schoemaker et al., 2013; Ram, Montibeller, 2013; De Smedt et al., 2013; and others] and analyses case studies in specific sectors, for example, bio-products and medical technology [ Wydra, 2015], energy [Fortes et al., 2015], the 'green' vehicle market in China [Qian, Soopramanien, 2015], and institutional conditions for commercializing biotechnologies in Germany and Japan [Lehrer, Asakawa, 2004], etc. Social and political measurements are also added to analyses on the effects of technologies and the priority selection process: STEEPV models (Social, Technological, Economic, Ecological and Public Values) [Misuraca et al., 2012; Eerola, Miles, 2010; Saritas, Aylen, 2010] and OCRIO models (Outcomes, Constraints, Rationale, Intervention, Objectives) [Mahroum, 2012].

Setting aside the numerous differences and various focuses of these studies, it is clear that they are all focused on improving foresight toolkits and techniques, paying virtually no attention to the relationship between the objects chosen by the authors. ${ }^{2}$ We propose expanding this branch of the literature to include

\footnotetext{
${ }^{1}$ For more on the evolution of the European approach to analysing the relationship between science (as a source of technology) and society based on the results of an analysis of projects supported during three framework programmes (1998-2010), see: [Rodriguez et al., 2013]; and on the application of the foresight methodology to identifying science and technology development priorities, see: [Georghiou, Harper, 2011 ].

${ }^{2}$ One unexpected example going against this general trend is an attempt to apply Luhmann's theory of social systems to understand technology [Herrera-Vega, 2015]. This is the only study with this analytical perspective in all the literature we reviewed.
} 
a connected theoretical framework: a social analysis of the relationship between humans and technology.

For this, following on from the diffusion of innovations concept, we start by looking at the stages that advanced (innovative) technologies go through before their contribution to a particular field becomes perceptible. We will then set out an additional methodological framework for the analysis: the theory of social construction of technology. With this, we will show how studies in the social sciences and humanities are connected to advanced technologies and could help to maximize their efficient use. In this part of the study, we will describe the corresponding directions of social research that are relevant to Russia in the near future and in the period up to 2030.

The implementation and prospects for mass dissemination of a particular technology resulting in the appearance of innovative products can be described through the diffusion of innovations mechanism. What is the role of the social sciences and humanities in this process? There are two forms of innovation 'implementation': adoption and diffusion. The first is on a micro level, describing the behaviour of individuals: whether they adopt an innovation for themselves, to what extent and why; the second is at a macro level: how the innovation spreads across the whole population over time [Straub, 2009, p. 626]. The implementation of technologies is linked to three successive decisions: 1) on using the technology; 2) on the 'depth' of its adoption, i.e., the extent to which the opportunities offered by the technology are realized; and 3) on speed, from replacement of the old with the new [Astebro, 2004, p. 381]. The most important condition for all three of these decisions is that implementing a new technology takes place in a certain social and organizational environment, whether or not this environment is ready to adopt that technology. In other words, assessing the possibility and success of implementing a technology requires an understanding of the social context in which it will be used in future.

The relationship with technology stems from a certain balance in the assessment of risks, benefits and trust in the entity introducing the technology [Sjöberg, 2002]. Sociological studies help to analyse sunk costs resulting from a subjective (human or organizational) lack of preparedness for new technologies and their perception.

In his classic work 'Diffusion of Innovation' (1962), Everett Rogers starts with the words of Benjamin Franklin: 'To get the bad customs of a country changed and new ones, though better, introduced, it is necessary first to remove the prejudices of the people, enlighten their ignorance, and convince them that their interests will be promoted by the proposed changes' and formulates this hypothesis in more rigid terms: 'Diffusion is the process by which (1) an innovation (2) is communicated through certain channels (3) over time (4) among the members of a social system' [Rogers, 1983, p. 5]. All three of the stages (2-4) not linked to the actual creation of an innovation (1) fall under the remit of the humanities and social sciences.

In fact, these stages do not necessarily occur sequentially. At first glance, the secondary circumstances (which according to Rogers come after creating the innovation) are in fact factors underpinning the formation of the innovation from the very start:

'It is often believed that at the beginning of the process of innovation the problems to be solved are basically technical and that economic, social, political, or indeed cultural considerations come into play only at a later stage... Right from the start, technical, scientific, social, economic, or political considerations have been inextricably bound up into an organic whole. Such heterogeneity and complexity, which everyone agrees is present at the end of the process, are not progressively introduced along the way. They are present from the beginning' [Callon, 1987, p. 84].

In the social sciences, several theories have been developed to explain the interaction between humans and technology (and the creation of technological innovations is a special case of these interactions): Actor-Network Theory (ANT) 
[Callon, 1987]; Social Construction of Technology (SCOT) [Bijker et al., 1987; Bijker, 2001]; and Socio-Technical Interaction Networks (SKIN) [Kling et al., 2003]. One of these is rooted in philosophy (ANT), viewing human and material objects symmetrically in relation to one another and analysing the role they plan in designing and reproducing everyday social practices. The others are geared towards a more applied analysis, focusing on the role of social groups in the process of designing technologies (SCOT) or in certain fields, for example information and communication technologies (SKIN). ${ }^{3}$ A relatively large number of differences between these approaches exist, all feeding various scientific discussions. For us, however, what is important is that they all arose to counterbalance technological determinism and, each in their own way, make up for its shortcomings.

In the case of innovative technologies, where different social groups have an inherent interest in implementing the results of innovations, it is more appropriate to select the Social Construction of Technology (SCOT) methodology as a framework. This theory identifies the following elements of an analysis, which when examined in series, describe the life cycle of technology in society [Bijker, 2001]:

- stakeholders, or relevant social groups (those who are in some way linked to the development or use of the technology);

- interpretative flexibility, or the multiple interpretations of a technology (as perceived by various social groups);

- the technological framework of interaction (between members of relevant social groups);

- 'closure' and stabilization (consolidating a particular format of interactions between social groups when using a technology);

- mutual interference, co-creation (continuous interaction between humans and technology and mutual transformation, as a result).

In other words, first the main stakeholders (social groups) are identified, their perception of the technology is reconstructed, together with the perceived pros and cons of the technology, and then the process of coordinating different groups' interests is analysed. After that, the technology is still not yet called into question, but is rather taken as a norm - before the next round of discussion, when new arguments arise for any of the relevant social groups.

Karl Polanyi and Mark Granovetter introduced the notion of 'social embeddedness of economic action' to economic sociology [Polanyi, 2001; Granovetter, 1985]. Granovetter focused on the micro- (individuals), while Polanyi looked at the macro-level (the relationship between the state and the economy). ${ }^{4}$ In essence, the concept of social embeddedness lies in the fact that economic actions are carried out not by atomized actors, but are rather built into specific social relationships between living individuals, and these relationships affect which economic results are ultimately achieved. By way of analogy, we suggest viewing 'social embeddedness of technology' as a key factor upon which the success of adoption, and at times the very configuration of a technology, depends.

\section{Technology clusters with a high degree of social embeddedness}

In virtually all countries which have prepared strategic documents outlining the goals of scientific activity, we see the same societal challenges currently facing humanity. The precise wording and foci may differ, but the material scope of the new technologies remains almost unchanged: medicine, natural resources, energy, the climate, the environment, and security. We are not concerned with analysing specific technologies identified in different countries as priorities to overcome a particular 'hurdle.' What is important for us is to show the possibility of bringing together methodological progress in the social sciences with the task of identifying science and technology development priorities. Therefore, for clarity, we have chosen the list of critical technologies in the Russian Federa-

\footnotetext{
${ }^{3}$ For more on key contemporary social theories explaining the interaction between humans and technology, see: [Lievrouw, 2006; Meyer, 2007; Bartis, 2007; Pinch, Swedberg, 2008].

${ }^{4}$ For a detailed review comparing these two classic paradigms, see [Krippner, Alvarez, 2007].
} 
tion as the strategic document to be analysed. ${ }^{5}$ On the one hand, the example is laconic and is therefore easy to understand, and on the other hand, it is the result of complex expert work. ${ }^{6}$ From this list, we have identified 18 of the more 'socially embedded' technologies based on an assessment of their potential social and economic effects and have grouped them into four clusters (Table 1). The proposed grouping is not methodologically rigorous. Technologies have been grouped according to industry while their social embeddedness has been identified through expert analysis: the human factor is implied in them, their end 'customer' or key consumer is human.

For each cluster, we look at the relevant 'social' problems and describe research trends in the social sciences and humanities, which, through a more in-depth understanding of the context and an ability to predict consequences, will contribute to a more effective implementation of certain technologies. In describing the research trends for each cluster, we identify characteristic parameters of the cluster in line with SCOT theory:

- relevant social groups;

- multiple interpretations of the technologies;

- a technological framework for interaction.

The two final parameters - 'closure' and mutual transformation - can only be described after the technology has been implemented on a basic level. In addition, we first need to study, from a sociological point of view, how the technologies in question have been (or are) implemented. Moreover, since we will be discussing prospective research directions (i.e. desirable but not yet in progress), in most cases the structure of our reasoning - according to the SCOT format will become clearer once the studies have been carried out.

Thus, we proceed to describe the desirable research directions for our clusters of technologies.

\section{Prospective directions in research}

The research directions that we will enumerate have been selected from a programme of prospective research in the social sciences and humanities. It was developed in 2014 through expert discussions aimed at honing down the most urgent societal challenges for Russia and suggesting a possible role for the social sciences and humanities in overcoming these challenges. ${ }^{7}$

Table 1. Critical technologies with a high degree of social embeddedness

Cluster 1. Biomedicine, health

1. Biocatalytic, biosynthetic and biosensor technologies.

2. Biomedical and veterinary technologies.

3. Genome, proteome and post-genome technologies.

4. Cellular technologies.

5. Nano-, bio-, information, cognitive technologies.

6. Bioengineering technologies.

7. Technologies to reduce loss from socially important diseases.

Cluster 3. The Environment

1. Technologies to monitor and forecast the state of the environment and to prevent and eliminate pollution.

2. Technologies to search for, prospect for and develop mineral deposits and extract them.

3. Technologies to predict and eliminate natural and manmade disasters.
Cluster 2. Energy

1. Nuclear energy, nuclear fuel cycle, safe handling of radioactive waste and processed nuclear fuel technologies.

2. New and renewable energy sources technologies, including hydrogen energy.

3. Technologies to create energy-saving energy transportation, distribution and consumption systems.

4. Technologies for energy-efficient production and transformation of energy from fossil fuels.

\section{Cluster 4. Transport and travel}

1. Technologies to create high-speed means of transport and smart management systems for new forms of transport.

2. Technologies to develop next-generation space rocket and transport technology.

3. Information, control and navigation system technologies.

4. Broadband multimedia service access technologies.

Source: compiled by the authors.

${ }^{5}$ The current list of critical technologies was approved by Order of the President of the Russian Federation no 899 dated 07.07.2011. Available at: http://kremlin.ru/ref_notes/988, accessed 28.01.2015.

${ }^{6}$ The method used to identify critical technologies is set out in the work [Sokolov, 2007].

More than 180 Russian and foreign experts took part in the project. In addition to the various forms of expert discussions, the results of a bibliometric analysis based on data from Web of Science and Scopus for 2003-2013 were also used. A detailed report on the results of the project will be prepared for publication in 2015 


\section{Cluster 1: Social research on biomedicine and health technologies}

The technologies grouped into this cluster will have a perceptible impact on the health of a nation. Health, while pertaining to the physical world, is largely socially conditioned: aside from genetics, it is linked to lifestyle and everyday habits, but is also connected with whatever quality of life is considered to be the norm in a given society and, consequently, how the health care system is built and the logic governing that system. Therefore, it is appropriate to examine the social prerequisites and consequences of biomedical technologies in two planes: in the context of the health care model and from the perspective of society's readiness (including at the level of certain individuals) to use the results of such developments.

For the technologies to be implemented to such an extent that they are used to their fullest extent (the effective 'depth' of innovation's adoption) [Åstebro, 2004], their 'social' parameters must be compatible with existing health care model parameters. We use the term social parameters of technologies to refer to the parameters determined by the social purpose of the development. They are dependent on how the technology will be applied in society: which social groups the technology is geared towards and what the proposed scale of its diffusion and accessibility will be.

Relevant social groups. The development of medicinal products and biomedical technologies affects doctors and patients, members of the pharmaceutical industry, marketing consultants, and regulators.

Multiple interpretations. The notion of a 'safe and effective drug' depends on the views invested in the drug by the various participants in a process, as well as on how these participants solve contradictions arising as a result of conflicts between different reasonings [Shulgina, 2014]. For patients, the perception of new drugs can be associated with 'invisible risks.' They are rooted in the 'social unconsciousness', either due to macro- or micro-social mechanisms or as a result of deliberate operations by certain actors [Stankiewicz, 2008, p. 56]. This calls for a social and economic analysis of the development of medicinal products, the processes through which they are brought to market and drug prescription practices by Russian doctors. It also calls for monitoring of the state's involvement in controlling and carrying out expert inspections on the pharmaceutical market.

A technological framework for interaction. Starting from the late 2000s, the health care system in Russia has undergone a process of active reform. These reforms set out to solve problems linked not only to raising the efficiency of the system's operations, but also to searching for new health care models, including models based on preventive principles [Government of the Russian Federation, 2008]. These models, geared towards preventing illness and early detection, are more financially advantageous to the state, and in the long-term will undoubtedly help to improve the population's quality of life. Preventive health care, in turn, should take into account the social structure of society and inherent in it forms of inequality.

In relation to the development of a preventive health care model i.e. in defining the focus of new biomedical developments, four major directions of social research can be identified:

- health inequality;

- raising living standards and the population's quality of life;

- mental health;

- the marketization of health care.

Health inequality is a relatively new but extremely pressing issue for Russian society today. It became especially evident during the transitional period, when the economic stratification increased, while access to and the quality of medical care for certain social groups dropped [Burdyak et al., 2008]. Health inequality manifests itself at the level of individuals and at the level of society as a whole. A situation where such inequality starts to be steadily reproduced, giving rise to social polarization, growing tension and increased spending in the social sphere, including on health care, is a major problem. This can have a significant impact 
on individuals' life chances, cause discrimination on the labour market, intensify the disparity of access to education, lead to growth in relative poverty, reduce productivity in various economic sectors, etc.

To develop preventive health care models, aside from genetics, the social factors of the risk of illness need to be studied. Without such studies, it will not be possible to identify the most vulnerable social groups in this regard. Inequality does not boil down to financial capabilities, but is caused by the effect of the external living environment, cultural practices, and ethical issues raised by treatment [European Commission, 2011; LERU, 2013; ISSC, 2010, 2013].

Studies at the juncture of sociology, demographics (forecasting mortality rates, birth rates, life expectancy) and health economics, on the one hand, and genetics (compiling 'genetic health cards'), neuropsychology, molecular biology and biomedicine, on the other hand, help to conceptualize the notion of health and deviations from the idea of health. They make it possible to improve professional medical practice, by providing doctors with data and instruments which the latter can use to predict the spread of diseases and organize medical support based on preventive principles. They can also help to raise awareness about the importance of creating personalized health cards, conducting genetic testing geared towards the end user, and genetic patient consultation.

Sociological studies of the mechanisms by which epidemiological threats spread will help to develop preventive principles. Amid growing globalization, the increase in migrational flows from developing countries and the expansion of tourism in Russia, citizens' domestic and international mobility is intensifying. As such, analysing potential epidemiological threats is of particular importance. To prevent such threats, we need a comparative assessment of the risk factors and an understanding of the social mechanisms by which illnesses and viruses spread. It is widely recognised that social networks play a fundamental role in the spread of disease [Granovetter, 1973], and so it would be advisable to monitor people's spatial movement across Russian territory and abroad, study how tourists communicate with the local population, identify vulnerable social groups from an epidemiological threat perspective, and identify the risk factors (habits, learning models and means of interaction) and mechanisms to reduce their effects. We need to analyse the social aspects of epidemic spread and develop models to increase population immunity. In particular, we need to study how myths about disease arise, devise ideas on the reasons for their spread, and formulate notions of effective treatment, among other things. Social studies will make it possible to elaborate effective measures to prevent epidemiological threats.

Raising living standards and the population's quality of life requires a sociological understanding of the mechanisms by which ideas of health are formed and healthy lifestyle practices made popular. A healthy lifestyle is a controversial and multi-faceted notion, encompassing perceptions of healthy eating, physical activity, the number of hours' sleep, etc. In this respect, it is important to understand the culture of food consumption by various social groups, as well as the link between eating practices and group values, ecological attitudes, consumer competence, religious beliefs, and views on health.

We also need to examine which social circumstances, psychological attitudes and habits interfere with physical activity for certain population groups. Factors having a negative effect on the health of the population also need to be investigated: unhealthy eating, alcohol, tobacco and soft drug consumption, including assessing how accessibility affects consumption levels and models among various social groups, including through monitoring. Special attention should be paid to the younger generations, including teenagers, and the risk behaviour patterns exhibited by them. To work on effective responses, we need to study the role of doctor's practices and medical discourse in shaping people's perceptions of a healthy lifestyle, including in solving problems of excess or insufficient weight. An understanding is needed of which views on healthy lifestyles are formed in a family and passed on to children. It would be worth looking at the limitations and opportunities offered by new technologies and the means of communicating and spreading social perceptions in the popularisation of healthy living models. 
Without such research, we will continue to see societies where problems linked to excess or insufficient weight, smoking, consumption of alcohol or harmful foods are not perceived as important; there will be no understanding of their scale or impact on the health of the nation overall, including in the long-term. As a result, resources to develop the corresponding infrastructure and ensure that large swathes of the population are following a healthy lifestyle are insufficient: sports establishments, mass media, including specialist information resources, businesses producing organic food, etc.

Interdisciplinary research on alcohol, drug and tobacco dependence will help to understand the reasons why various social groups are drawn to the consumption of illegal products and are prepared to put their own health at serious risk. This makes it possible to show the impact of education and material welfare on the scale of alcohol, tobacco and drug consumption in society, by providing tools to monitor and assess the effectiveness of state programmes to combat smoking and drug use.

Mental health is an important component of health, and psychological disorders imply high indirect costs: economic and social spending on psychological conditions far exceeds spending on diabetes or cancer treatment [European Commission, 2011; LERU, 2013]. The role of preventive medical technologies is particularly high in this sphere.

Psychological disorders are of course classified as socially important conditions i.e. those which 'are caused predominantly by socio-economic conditions, harm society and require social protection for individuals' [Ministry of Health, 2013]. Of course, in this case we cannot say that social and economic factors are the primary cause, but their contribution in terms of preventing or intensifying such conditions is often critical. On a societal level, mental health can affect mass behaviour in general.

Mental health goes beyond the absence of disorders in a strictly medical sense. To a large degree, it is determined by subjective well-being (emotional, human, psychological), which includes life satisfaction, the balance of positive and negative emotions, social attitudes, etc. This gives rise to questions about the social and historical notions of norms and deviations from the norm. From a sociological perspective, it is also important to examine the transformation of psychiatry as a social institution, in particular in terms of dealing with people suffering from psychological conditions.

Mental health (just like subjective well-being) is shaped by a wide range of social, economic, political, and technological factors. Psychological well-being helps to motivate people into long-term activity. It is therefore important to study the link between mental health and employment: phenomena such as tiredness, fatigue, professional burn-out, overtime, occupational safety, mass insanity amid growing information loads, accelerating social processes, the development of ICT, and the increasing complexity of the world around us. Studies that investigate mental health and subjective well-being also make it possible to record increasing depression and growing tension in society in good time, which can have a knock-on effect on the health of the population as a whole, crime, etc. Poor understanding and lack of empirical information impede the identification of widespread psychological deviations, their social causes, and potential consequences, in particular in the workplace.

The marketization of health care is associated with growing dissatisfaction among the population and requires special institutional regulation to eliminate the increasing opposition between morals, technology and the market. These issues are important, for instance, on the growing organ transplant and surrogacy markets. They require both ethical solutions and an examination of institutional reasonings in the health care environment [Scott, 2004]. A lack of adequate research prevents regulators from monitoring the effectiveness of health care reforms and promoting the implementation of innovations in this sphere.

The connection between technology, the market, and morals is also considered in health literacy studies. It is important to conceptualize this notion, learn how to measure literacy levels, and identify factors affecting health literacy in mod- 
ern Russia. This will make it possible to assess the potential and real impact of new digital technologies and means of communication in doctors' practices. Moreover, it will become possible to develop ways to protect personal health care data and to control access to data. Research results will help to reveal Internet behaviour patterns, linked to how people search for information on health and treatment practices.

\section{Cluster 2: Social research on energy technologies}

Issues of raising energy efficiency and saving energy occupy an important place on the agenda of Russian state policy. It is believed that the growth seen in recent years in electricity demand could lead to a significant shortfall in the future and could be a major factor stunting the country's economic growth [Government of the Russian Federation, 2010]. We need to transition to sustainable electricity production and increase awareness and the level of end-user involvement in energy development.

Relevant social groups. The problem affects society in general, however the change in electricity consumption behaviour patterns between different social and demographic groups requires further analysis. Everyday electricity consumption culture and practices, peoples' willingness to take responsibility for energy saving and an awareness of civil liability are all pressing subjects in this regard (the latter concerns not only individuals, but businesses too). We need to study consumer literacy in terms of saving energy and the potential impact of new technologies and means of communication on changing behaviour patterns.

Multiple interpretations. Alongside research on reactions and attitudes on an individual level, it is important to assess the probability of and potential resistance points in society. A striking example of such research is the monograph [Hecht, 2009], which describes the interweaving of national identity and the development of the nuclear industry in France. In Russia, there are virtually no such studies. $^{8}$

A technological framework for interaction. The prospects of a possible future energy crisis giving rise to the development and use of renewable energy sources is much less intense in Russia than in Western European countries or the US [Government of the Russian Federation, 2010]. The emergence of alternative, cheaper sources of energy will affect the economy, including the labour market. Therefore, it is important to examine the conditions, opportunities, and social and economic consequences of a move from traditional to new forms of electricity production and cheaper sources of electricity, as well as the attitudes of citizens towards renewable energy.

\section{Cluster 3: Social research on natural resource management and environmental protection technologies}

Practices in natural resource management and energy consumption are largely shaped by social factors such as value systems and customs.

Relevant social groups. Practices in natural resource management are reflected in the behaviour of both individuals and businesses. Businesses are called upon to decide for themselves whether they will focus only on economic gain or also take into account principles of social responsibility, opting for less profitable, but more environmentally friendly technologies. Indeed, perceptions of technologies can be dependent on ideology [Plutzer et al., 1998]. Of course, in terms of the path that the business selects for itself, a significant role is played by public opinion, which in turn affects the business' reputation.

Multiple interpretations. In the context of attitudes towards the environment, it even makes sense to talk about features of national identity (as a more longterm parameter than transient public opinions). Often, social tolerance is analysed in relation to identity. Usually, this means tolerance towards the 'Other' (conceptualized as representing another culture, religion, etc.) In this case, it

${ }^{8}$ Among the few works are studies carried out in 2007 and 2010 by the ZIRCON group on 'Diagnosing social attitudes in zones of real and potential nuclear energy businesses.' For more information, see: http://www. zircon.ru/about/our-works/2007_2010/, accessed 28.01.2015. 
is more about analysing tolerance towards practices that are not conducive to sustainable natural resource management, such as the impact tolerance has on modernization [Shcherbak, 2013].

A technological framework for interaction. For this technology cluster, social analysis of interactions between stakeholders should focus on two research directions:

- the societal consequences of climate change;

- the development of eco-mindedness and environmentally friendly behaviour among the population.

Climate change and its social consequences are a global problem, the solutions for which fall largely within the realm of the natural sciences. However, the approaches proposed by natural scientists of ten prove ineffective, as people simply fall back on social norms and traditions in their behaviour or are guided by another rationale not based on natural scientific reasoning. Empirical studies of social reactions to climate change (both assumed and real) and the perceptions of different social groups to climate trends and cycles are of great interest. No less important are questions of adapting people to climate change, which could have both positive and catastrophic social and natural consequences. In this regard, it is important to study the discourses on climate change, in particular on global warming, and to compare how these discourses are demonstrated indirectly in everyday life with peoples' perceptions. We also need to assess the impact of climate change on the health of the population, including psychologically.

Studies on climate change promote awareness of its potential and real positive and negative effects for society and justify responses to prevent natural disasters. They also bring an understanding of the contextual and local rationale which guides people in their behaviour by reacting to changes in climate conditions, adapting to and surviving catastrophic natural phenomena (for example, drought, forest and peat fires, disruption of the environmental equilibrium, etc.) [Sobolev, 2012].

The development of eco-mindedness and the diffusion of environmentally friendly behaviour among the population. To effectively manage a resource-driven economy, there needs to be an adequate understanding of the social history and culture of a territory: how the system of production came to be and how it developed, how producers and consumers adapted to one another, and how they affected the landscape. A vast territory and plenty of natural resources, characteristic of European countries among others, affect the distinct nature of national economies and societies. We therefore need to study the interactions between the size of a country and the practices of managing people and natural resources (land, forests, water, etc.) [Radkau, 2000]. The challenge here are the non-market and unlawful means of distributing resources (unauthorized taking by force, poaching, etc.) and the social conflicts caused by these approaches, the consequence of which is social demand for fair, institutionalized distribution of natural resources and conflict settlement.

There is a need to study the extent to which environmental pollution by the population is done consciously and to examine the mechanisms by which ecomindedness is formed. These include everyday environmental knowledge, attitudes, values, perceptions of 'clean' and 'dirty', the relationship between ideologies and eco-mindedness, the relationship between eco-mindedness and environmentally friendly practices by different social groups, including social surveys of waste management [European Commission, 2011; MRU, 2013], domestic waste processing and recycling technologies and studies of the lives of homeless people and their dealings with waste. We need to analyse mass initiatives to protect the environment and spread environmentally friendly attitudes and behaviour, and examine existing mechanisms to control and distribute natural resources in society from the perspective of 'fairness' and other criteria.

These studies should be compemented by an exploration into the hierarchy of threats in the collective consciousness (physical, material, reputational, etc.). 
This would make it possible to conceptualize the contextual and local rationales which guide various social groups in their decision making as to natural resources. Taking these rationales into account, it would then be possible to correct peoples' patterns of behaviour with natural resources (controlling for their social positions, attitudes, and values), develop tools to prevent social tension and political conflict surrounding control over natural resources, and formulate a strategy of awareness-raising on effective natural resource management.

\section{Cluster 4: Social research on transport development technologies}

In Russia, domestic migration is currently on the wane. Migration flows have been uneven and are largely becoming uni-directional with large cities being their main destination, active urbanization is continuing. This suggests sociological analysis of city branding, restructuring and reform of city space, and the creation of transport-free zones.

The relevant social groups are city residents, mobile groups of the population, and customers and developers of systems that use geo-data (businesses and municipal authorities). The mechanisms and opportunities to encourage settling in Russian cities and towns, new forms of migration (downshifting, reverse migration, commuting, etc.), and the factors shaping these trends should be of keen interest to the social sciences.

Multiple interpretations. The research agenda involves analysing consumer preferences in terms of transport (their 'environmental friendliness', economy, etc.) and travel methods (public or private transport, or combinations of the two). There is a need to study the consequences for peoples' lives of increased or reduced time spent commuting, as well as the contribution of ICT, distance learning methods and remote working to meet popular demands for less physical travel.

A technological framework for interaction. Geographic information systems are of growing importance for the development of regions, towns and cities. Their widespread application is possible thanks to integration with non-spatial databases and mobile technologies. Geographic information systems in turn could serve sociological purposes too, for instance to map value systems and interests. From a sociological perspective, it is worth paying attention to the growing demand from businesses, the population, and municipal authorities for such geodata and the contribution of amateur users to data generation.

To change the intensity and directions of domestic travel, we need to study regional mobility and the impact of space management on the lives of people and society. This will make it possible to identify the most dynamic population groups and highlight the factors contributing to or inhibiting domestic mobility. It will also mean that we can develop tools which can help to lock in social imbalances arising as a result of falling public demand for physical travel. Such reduced demand for physical travel is, in turn, due to new technologies or forms of communication (for example, the falling spatial accessibility of cultural sites). Finally, research in these areas will enable us to understand the factors contributing to regional identity crises. The results obtained will help to explain Russian tourism practices and Russians' consumption preferences in terms of holiday destinations, which could in turn serve to develop attractive city brands and implement an effective transport policy.

In the long-term, humanity will more actively develop not only horizontal but vertical space, which will invariably have an impact on the construction sector and on the production of means of transport, etc. [Utyasheva, 2014] In this regard, the time has now come for us to seriously consider the possibility of creating 'smart cities', comprising self-sufficiency, integrated management, and electronic government [Moir et al., 2014].

\section{Conclusion}

The natural and technical sciences are often contrasted to the social and human sciences: while the former examine natural phenomena in the physical world 
(nature-dominated), the latter are focused on human and social interactions (human-dominated). However, the range of problems facing humanity now often requires contributions from both fields. The problem itself might lie in the physical plane and be independent of people in this respect (for example, the state of water basins, the air), yet solving such problems requires both technological efforts and a certain involvement from society through the shaping of attitudes and behaviour patterns which could minimize environmental pollution [Bastow et al., 2014].

We have shown that at the juncture of the physical and the social lie many advanced technologies. Their development plays out in the physical plane, but their effective implementation and use is of ten inconceivable without the social context for which they were created and in which they exist.

On the list of critical technologies for the Russian Federation (the succinct case study strategic document defining science and technology development priorities), we identified those priorities where the level of social embeddedness potentially reaches its maximum. Realizing these priorities in full will only be possible with an understanding of the associated social attitudes and circumstances. These priorities were broken down into four groups ('clusters'): biomedicine and health, energy, the environment, and transport.

For each 'cluster', we identified prospective research directions in the social sciences and humanities which will make it possible to render the technologies more effective through a more reliable assessment of the context surrounding their development and diffusion. To do this, we applied the methodological framework of the Social Construction of Technology theory, having analysed the composition of social groups affected by these technologies and their potential conflicts of interests.

As this study looks at prospective research, we only considered those elements of social circumstances that, according to SCOT theory, can be foreseen at the technology implementation phase for each cluster: relevant social groups, multiple interpretations of a technology, and the likely types of interaction between groups. Further diffusion of a technology must be accompanied by studies on their 'stabilization' processes for certain social groups and monitoring of the changes that corresponding changes in configuration could entail.

Among such changes are the possible consequences of developing technologies that are hard to assign to one particular field, but which could lead to a fundamental transformation in society. This relates, primarily, to the emergence of 'new subjects' in society, especially in the employment sphere (social robots, personalized virtual agents, etc.) amid the rapid development of artificial intelligence technologies. Studies in this area might start with an analysis of hybridization and autonomous control processes, especially in health care, the education system, large-scale industry and agriculture. However, it is important to examine the negative effects of a technology's diffusion and increasing automation: for example, we see a loss of professional qualifications (including doctors, surgeons, architects, airline pilots, etc.) and at the same time, growing competition between robotic technologies [Carr, 2014]. Studying peoples' readiness to interact with technological subjects which carry human values, interests and individuality is linked to this topic [Smart, 2014]. The distinction between the virtual environment and the real world is gradually wearing down while the importance of research at the juncture of 'spatial movement - new technologies - anxieties about health' [Skyscanner, The Future Labs, 2014] is increasing.

Thus, we contend that many prospective technologies, which are material in nature, prove more effective if their implementation and, potentially, elements of their development are accompanied (and often anticipated) by the results from corresponding studies in humanities and social sciences. We introduce the 'social embeddedness of technology' notion and consider it a significant factor upon which the success of an innovation - and of ten, the very configuration of a technology - hinges. 


\section{References}

Åstebro T. (2004) Sunk costs and the depth and probability of technology adoption. The Journal of Industrial Economics, vol. LII, no 3, pp. 381-399.

Bartis E. (2007) Two suggested extensions for SCOT: Technological frames and metaphors. Society and Economy, vol. 29, no 1, pp. 123-138.

Bastow S., Dunleavey P., Tinkler J. (2014) The Impact of Social Sciences: How Academics and Their Research Make a Difference, London: Sage Publications.

Bijker W.E. (2001) Social Construction of Technology. International Encyclopedia of the Social \& Behavioral Sciences (eds. N.J. Smelser, P.B. Baltes), vol. 23, Oxford: Elsevier Science Ltd, pp. 15522-15527.

Bijker W.E., Hughes T.P., Pinch T. (1987) The Social Construction of Technological Systems: New Directions in the Sociology and History of Technology. Cambridge, MA: The MIT Press.

Bremer S., Millar K., Wright N., Kaiser M. (2015) Responsible techno-innovation in aquaculture: Employing ethical engagement to explore attitudes to GM salmon in Northern Europe. Aquaculture, vol. 437, pp. 370-381.

Burdyak A., Selezneva E., Shishkin S. (2008) Razlitchiya v dostupnosti meditsinskoi pomoshchi dlya naseleniya Rossii [Differences in access to healthcare for the population of Russia]. SPERO. Sotsialnaya politika: ekspertiza, rekomendatsii, obzory [SPERO. Social policy: Expertise, Recommendations, Reviews], no 8, pp. 135-158 (in Russian).

Callon M. (1987) Society in the Making: The Study of Technology as a Tool for Social Analysis. The Social Construction of Technological Systems (eds. W.E. Bijker, T.P. Hughes, T. Pinch), Cambridge, MA: The MIT Press, pp. 83-103.

Carr N. (2014) The Glass Cage: Automation and Us, New York: W.W. Norton and Company, Inc.

CEC (2000) Science, Society and the Citizen in Europe, Brussels: Commission of the European Communities. Available at: http://ec.europa.eu/research/area/science-societyen.pdf, accessed 20.02.2015.

De Smedt P., Borch K., Fuller T. (2013) Future scenarios to inspire innovation. Technological Forecasting and Social Change, vol. 80, pp. 432-443.

Eerola A., Miles I. (2010) Methods and tools contributing to FTA: A knowledge-based perspective. Futures, vol. 43, no 3, pp. 265-278.

European Commission (2011) Horizon-2020 - The Framework Programme for Research and Innovation (COM(2011)808 final), Brussels: European Commission. Available at: http://eur-lex.europa.eu/legal-content/EN/TXT/PDF/?uri=CELEX: 52011DC0808\&from=EN/, accessed 17.02.2015.

Forsberg E.-M., Quaglio G.-L., O’Kane H., Karapiperis T., Woensel Van L., Arnaldi S. (2015) Assessment of science and technologies: Advising for and with responsibility. Technology in Society, vol. 42, pp. 21-27.

Fortes P., Alvarenga A., Seixas J., Rodrigues S. (2015) Long-term energy scenarios: Bridging the gap between socioeconomic storylines and energy modeling. Technological Forecasting and Social Change, vol. 91, pp. 161-178.

Frewer L.J., Gupta N., George S., Fischer A.R.H., Giles E.L., Coles D. (2014) Consumer attitudes towards nanotechnologies applied to food production. Trends in Food Science and Technology, vol. 40, no 2, pp. 211-225.

Georghiou L., Harper J.C. (2011) From priority-setting to articulation of demand: Foresight for research and innovation policy and strategy. Futures, vol. 43, pp. 243-251.

Government of the Russian Federation (2008) Kontseptsiya dolgosrotchnogo sotsial'no-ekonomitcheskogo razvitiya Rossiiskoi Federatsii na period do 2020 goda (utverzhdena rasporyazheniem Pravitelstva RF № 1662-r ot 17.12.2008 g.) [The concept of long-term socio-economic development of the Russian Federation until 2020 (approved by the governmental decree no 1662-r dated 17.12.2008)] (in Russian).

Government of the Russian Federation (2010) Gosudarstvennaya programma energosberezheniya i povysheniya energetitcheskoi effektivnosti na period do 2020 goda (utverzhdena rasporyazheniem Pravitel'stva RF № 2446-r ot 27.12.2010 g.) [The state program of energy conservation and energy efficiency until 2020 (approved by the governmental decree no 2446-r dated 27.12.2010)] (in Russian).

Granovetter M. (1973) The Strength of Weak Ties. The American Journal of Sociology, vol. 78, no 6, pp. 1360-1380.

Granovetter M. (1985) Economic Action and Social Structure: The Problem of Embeddedness. American Journal of Sociology, vol. 91, pp. 481-510.

Hecht G. (2009) The Radiance of France: Nuclear Power and National Identity after World War II, Cambridge, MA: MIT Press.

Herrera-Vega E. (2015) Relevance of N. Luhmann's theory of social systems to understand the essence of technology today. The Case of the Gulf of Mexico Oil Spill. Technology in Society, vol. 40, pp. 25-42.

ISSC (2010) World Social Science Report 2010, Paris: International Social Science Council. Available at: http://www. worldsocialscience.org/activities/world-social-science-report/, accessed 27.11.2014.

ISSC (2013) World Social Science Report 2013, Paris: International Social Science Council. Available at: http://www. worldsocialscience.org/activities/world-social-science-report/, accessed 27.11.2014.

Kling R., McKim G., King A. (2003) A bit more to IT: Scholarly communication forums as socio-technical interaction networks. Journal of the American Society for Information Science and Technology, vol. 54, no 1, pp. 47-67.

Krippner G.R., Alvarez A.S. (2007) Embeddedness and the intellectual projects of economic sociology. Annual Review of Sociology, vol. 33, no 1, pp. 219-240.

Lehrer M., Asakawa K. (2004) Rethinking the public sector: Idiosyncrasies of biotechnology commercialization as motors of national R\&D reform in Germany and Japan. Research Policy, vol. 33, pp. 921-938.

LERU (2013) The Future of the Social Sciences and Humanities in Europe: Collected LERU papers on the SSH research agenda (ed. W. van den Doel), Leuven: League of European Research Universities.

Lievrouw L. (2006) New Media Design and Development: Diffusion of Innovations versus Social Shaping of Technology. Handbook on New Media: Social Shaping and Consequences of ICTs (eds. L. Lievrouw, S. Livingstone), London: Sage, pp. 246-252. 
Mahroum S. (2012) Innovation Policies and Socio-economic Goals: An Analytic-Diagnostic Framework (INSEAD Working Paper 2012/35/IIPI), Fontainebleau: INSEAD. Available at: http://papers.ssrn.com/sol3/papers.cfm?abstract_id=2026444, accessed 20.02.2015.

Meyer E.T. (2007) Socio-Technical Perspectives on Digital Photography: Scientific Digital Photography Use by Marine Mammal Researchers (PhD dissertation, ProQuest Digital Dissertations database Publication № AAT 3278467), Indiana, Bloomington: Indiana University.

Ministry of Health (2013) Sotsial'no znachimye zabolevaniya naseleniya Rossii v 2012 godu (statisticheskie materialy) [Socially significant diseases of the population of Russia in 2012 (statistical data)]. Moscow: Ministry of Health of the Russian Federation (in Russian).

Misuraka G., Broster D., Centeno C. (2012) Digital Europe 2030: Designing scenarios for ICT in future governance and policy making. Government Information Quarterly, vol. 29, pp. S121-S131.

Moir E., Moonen T., Clark G. (2014) What are Future Cities? Origins, Meanings and Uses, London: Government Office for Science, Future Cities Catapult.

MRU (2013) Horizons for Social Sciences and Humanities. Conference Report (eds. K. Mayer, T. Konig, H. Nowotny), Vilnius: Mykolas Romeris University Publishing. ISBN 978-9955-19-625-9.

Pinch T., Swedberg R. (eds.) (2008) Living in a Material World: Economic Sociology Meets Science and Technology Studies, Cambridge, MA; London: MIT Press.

Plutzer E., Maney A., O’Connor R.E. (1998) Ideology and Elites' Perceptions of the Safety of New Technologies. American Journal of Political Science, vol. 42, no 1, pp. 190-209.

Polanyi K. (2001) The Great Transformation: The Political and Economic Origins of Our Time, Boston: Beacon.

Qian L., Soopramanien D. (2015) Incorporating henerogeneity to forecast the demand of new products in emerging markets: Green cars in China. Technological Forecasting and Social Change, vol. 91, pp. 33-46.

Radkau J. (2000) Natur und Macht. Eine Weltgeschichte der Umwelt [Nature and power. A world history of environment], München: C.H. Beck Verlag (in German).

Ram C., Montibeller G. (2013) Exploring the impact of evaluating strategic options in a scenario-based multi-criteria framework. Technological Forecasting and Social Change, vol. 80, pp. 657-672.

Rodriguez H., Fisher E., Schuurbiers D. (2013) Integrating science and society in European Framework Programmes: Trends in project-level solicitations. Research Policy, vol. 42, no 5, pp. 1126-1137.

Rogers E. (1985) Diffusion of Innovation (3rd ed.), New York: The Free Press.

Saritas O., Aylen J. (2010) Using scenarios for roadmapping: The case of clean production. Technological Forecasting and Social Change, vol. 77, pp. 1061-1075.

Schoemaker P.J.H., Day G.S., Snyder S.A. (2013) Integrating organizational networks, weak signals, strategic radars and scenario planning. Technological Forecasting and Social Change, vol. 80, pp. 815-824.

Scott R.W. (2004) Competing Logics in Health Care: Professional, State, and Managerial. The Sociology of the Economy (ed. F. Dobbin), New York: Russell Sage Foundation, pp. 267-287.

Shcherbak A. (2013) Sravnitel'nyi analiz vliyaniya tolerantnosti na modernizatsiyu [The Impact of Tolerance on Economic Modernization in a Comparative Perspective]. Foresight-Russia, vol. 7, no 4, pp. 6-14 (in Russian).

Shul'gina A. (2014) Kak sozdayutsya lekarstvennye preparaty [How are drugs created]. ESForum, no 3, pp. 11-17 (in Russian).

Sjöberg L. (2002) Attitudes toward Technology and Risk: Going beyond What Is Immediately Given. Policy Sciences, vol. 35, no 4, pp. 379-400.

Skyscanner, The Future Labs (2014) The Future of Travel 2024. Available at: http://www.skyscanner2024.com, accessed 19.02.2015.

Smart J. (2014) Tcherez pyat' let u nas budut tsifrovye bliznetsy [After five years we will have digital twins]. Metro, 27.10.2014. Available at: http://www.metronews.ru/novosti/dzhon-smart-cherez-pjat-let-u-nas-budut-cifrovye-bliznecy/ TponjA---9uBMyhvAF6uhw/, accessed 15.12.2014 (in Russian).

Sobolev A. (2012) Ispytanie ognem: vliyanie prirodnykh katastrof na polititcheskie predpotchteniya i sotsial'nyi kapital $\mathrm{v}$ sel'skoi Rossii [Trial by Fire: The impact of natural disasters on the political preferences and social capital in rural Russia]. Ekonomitcheskaya sotsiologiya [Journal of Economic Sociology], vol. 13, no 2, pp. 118-121 (in Russian).

Sokolov A. (2007) Metod krititcheskikh tekhnologii [Method of Critical Technologies]. Foresight-Russia, vol. 1, no 4, pp. 64-75 (in Russian).

Stahl B.C. (2013) Virtual suicide and other ethical issues of emerging information technologies. Futures, vol. 50, pp. 35-43.

Stahl B.C., Eden G., Jirotka M., Coeckelbergh M. (2014) From computer ethics to responsible research and innovation in ICT: The transition of reference discourses informing ethics-related research in information systems. Information \& Management, vol. 51, no 6, pp. 810-818.

Stankiewicz P. (2008) The Social Construction of Security. Polish Sociological Review, no 161, pp. 55-72.

Straub E.T. (2009) Understanding Technology Adoption: Theory and Future Directions for Informal Learning. Review of Educational Research, vol. 79, no 2, pp. 625-649.

Utyasheva V. (2014) «Arkhitekturnye fantazii»: doma v 1000 etazhei svyazhut reisovye dirizhabli [«Architectural Fantasies»: Houses of 1000 floors will be bound by shuttle airships]. Metro, 27.10.2014. Available at: http://www.metronews.ru/ novosti/doma-v-1000-etazhej-svjazhut-rejsovye-dirizhabli/TponjA---13fQKjTcS6Jc/, accessed 15.12.2014 (in Russian).

Wydra S. (2015) Challenges for Technology Diffusion Policy to Achieve Socio-Economic Goals. Technology in Society, vol. 41, pp. 76-90. 